\title{
The 2010 recipient of the Brady Medal: Professor Christopher Barnes
}

\author{
M. PAUL SMITH \\ School of Geography, Earth \& Environmental Sciences, University of Birmingham, Edgbaston, Birmingham B15 2TT, UK \\ (e-mail: m.p.smith@bham.ac.uk)
}

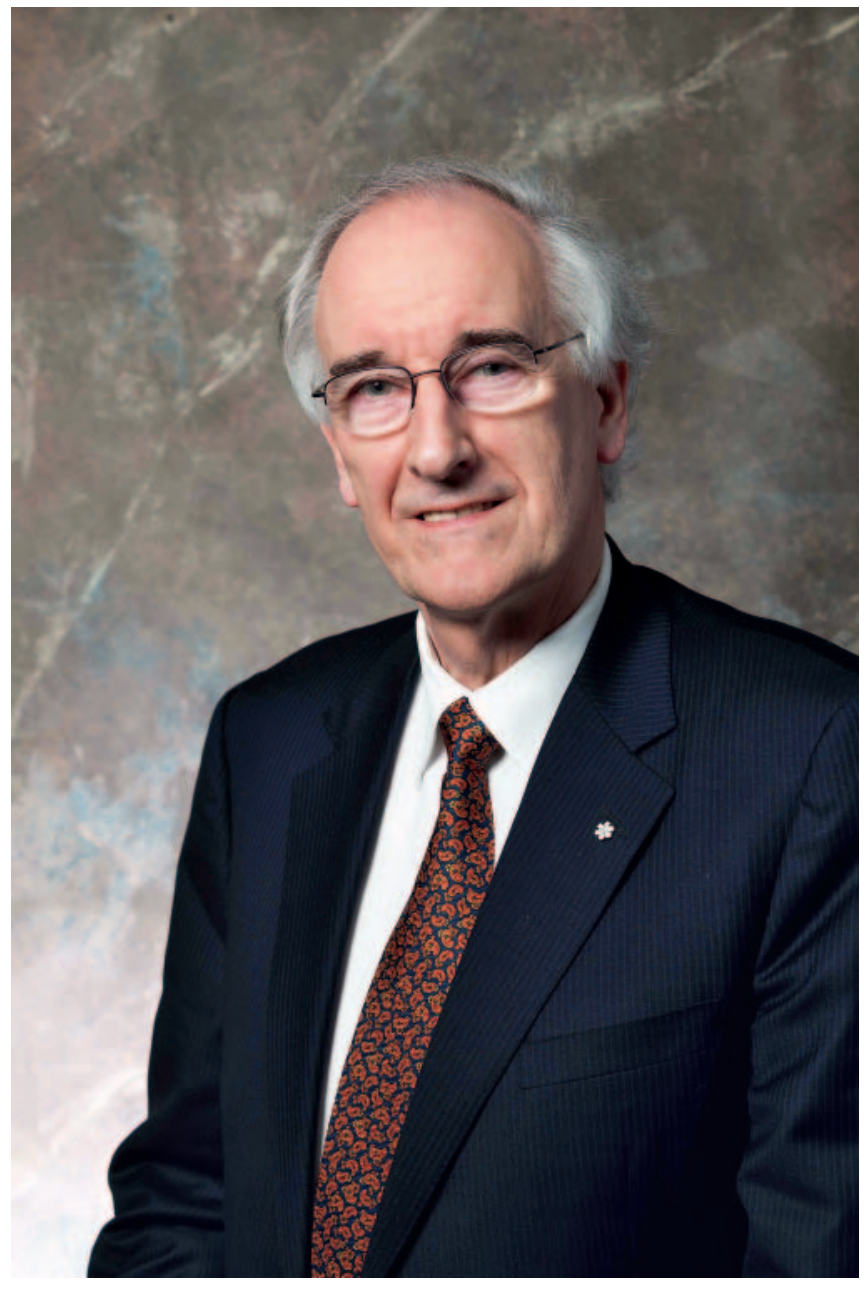

Chris Barnes graduated from the University of Birmingham in 1961 and moved to Canada, where he completed a doctoral degree at the University of Ottawa in 1964. Chris started his academic career by establishing a major centre of conodont research at the University of Waterloo where, based on his early work on the Ordovician of Ontario and Québec, he soon became one of North America's leading Early Palaeozoic conodont experts. In this capacity, he was one of the authors of the Middle-Upper Ordovician chapter in the landmark publication on North American conodont biostratigraphy published as Geological Society of America Memoir 127 in 1971 (Sweet et al., 1971). Although much of his early work was on biostratigraphy he diversified his research from the start, producing some of the earliest papers on conodont histology and ultrastructure (e.g. Barnes et al., 1973), on Lower Palaeozoic conodont provincialism and palaeoecology (e.g. Barnes \& Fåhræus, 1975; Fortey \&
Barnes, 1977) and on thermal maturation in conodonts and its application (e.g. Nowlan \& Barnes, 1987) - papers which have a marked influence on conodont research to this day. In the 1970s he devoted much of his energy to the Ordovician stratigraphy of northern Canada, publishing papers on stratigraphy and conodonts from Hudson Bay to the Arctic Islands, providing some of the earliest biostratigraphic benchmarks in that very remote region. The 1970s also saw the start of a campaign to document with co-workers the important Ordovician-Silurian succession of Anticosti Island, which resulted in a series of landmark taxonomic and biostratigraphic monographs documenting the conodont record in intricate detail (Nowlan \& Barnes, 1981; McCracken \& Barnes, 1981). In 1979, Chris and co-authors published a system of elemental notation for conodont apparatuses (Barnes et al., 1979) that was one of the first attempts to identify homologous elements across different apparatus types, searching in particular for homology between apparatuses composed of coniform element types and more derived types with ramiform-pectiniform elements. This paved the way for modern cladistic studies, in which Chris has also been an early adopter.

From 1975 to 1981, Chris served as Chair of Earth Sciences at Waterloo. Moving to a similar position at Memorial University of Newfoundland in 1981, he established the Centre of Earth Resources Research and, while based there, developed a large body of work on the Cambrian and Ordovician sediments of western Newfoundland. Together with $\mathrm{PhD}$ students and co-workers, he reconstructed in minute detail the biostratigraphy and spatial relationships of sequences representative of the Laurentian shelf margin through to mid-slope and distal environments. It is upon this work that the global stratotype for the base of the Ordovician is founded (Barnes, 1988). All this was achieved at the same time as guiding Memorial to a position as one of the leading geoscience departments in Canada.

From Newfoundland, Chris moved to the Geological Survey of Canada (1987-1989) where he served as Director General of the Sedimentary and Marine Branch, and was responsible for the offshore Frontier Geoscience Program. In 1989, Chris moved to the University of Victoria and developed a new conodont research programme based in western Canada. Following the Newfoundland model, he and his research students published a series of substantial papers on the Cambrian to Silurian strata of British Columbia. His move to Victoria was also marked by a broadening of research interests into palaeoceanography, and Chris used his considerable experience in the understanding of Early Palaeozoic history to write broadranging papers on Ordovician climate and ocean circulation, including strontium, neodymium and oxygen isotope studies using his extensive conodont collection (e.g. Trotter et al., 2008).

At the University of Victoria, Chris was Director of both the Centre of Earth and Ocean Research (1989-2000) and the School of Earth and Ocean Sciences (1991-2002), before 
becoming the NEPTUNE Canada Project Director in 2002. NEPTUNE Canada (Barnes et al., 2011) is the world's first regional-scale cabled ocean observatory network, and is located off the west coast of Vancouver Island, British Columbia. The network extends across the Juan de Fuca plate and gathers live data from an array of instruments deployed across a range of undersea environments. Data are transmitted via high-speed fibre optic communications from the seafloor to a data archival system at the University of Victoria, which provides free internet access to the substantial wealth of data, both live and archived, throughout the 25-year planned life of the project.

Chris has always been a highly effective and willing mentor, both on a formal basis to his graduate students and postdoctoral researchers, and informally to a wide range of international collaborators. Many have subsequently gone on to become leading international researchers in their own right within the international micropalaeontological community.

Chris has around 135 peer-reviewed papers, most of which are on conodonts, that span an impressive range of ground within and beyond the discipline. The portfolio of publications is particularly notable for its breadth of coverage, the strong and enduring influence of the early papers and the continuation of high profile outputs throughout Chris's career. There are very few areas of conodont studies where a major strand of research does not have a Barnes paper in the cluster of early, influential works. Although Chris has published mainly on Canadian material, he has also produced papers on conodonts from Argentina, Australia, China, Germany, Russia, Spitsbergen, the UK and the United States. His contribution to the detailed taxonomic study of conodonts, especially those from the Ordovician, is immense, but more than that, he has placed conodonts at the forefront of international research by using them to tackle large-scale questions relating to histology, phylogeny and ecology through to global oceanic circulation and climate.

Chris is already honoured in Canada as a recipient of the Order of Canada, a Fellow of the Royal Society of Canada, and a recipient of the Geological Association of Canada's Past Presidents, Elkanah Billings, J. Willis Ambrose and Logan medals, as well as the Bancroft Award of the Royal Society of Canada and the Queen's Golden Jubilee Medal. He is also a member of the National Academy of Sciences, Cordoba, Argentina. Chris Barnes has made an enormous mark on international micropalaeontology. In his conodont work he has made a global impact on stratigraphy and palaeobiology, and he is thus a very deserving recipient of the Brady Medal of The Micropalaeontological Society, the fourth award of this medal that the society has made.

\section{Manuscript received 2 July 2011 \\ Manuscript accepted 2 July 2011}

\section{REFERENCES}

Barnes, C.R. 1988. The proposed Cambrian-Ordovician global boundary stratotype and point (GSSP) in western Newfoundland. Geological Magazine, 125: 381-414.

Barnes, C.R., Best, M.M.R., Johnson, F.R., Pautet, L. \& Pirenne, B. 2011. Understanding Earth/ocean processes using real-time data from NEPTUNE Canada's widely distributed sensor networks, North-East Pacific. Geoscience Canada, 38: 21-30.

Barnes, C.R. \& Fåhræus, L.E. 1975. Provinces, communities and the proposed nektobenthic habit of Ordovician conodontophorids. Lethaia 8: 113-149.

Barnes, C.R., Kennedy, D.J., McCracken, A.D., Nowlan, G.S. \& Tarrant, G.A. 1979. Structure and evolution of Ordovician conodont apparatuses. Lethaia 12: 125-151.

Barnes, C.R., Sass, D.B. \& Monroe, E.A. 1973. Ultrastructure of some Ordovician conodonts. Geological Society of America Special Paper 141: $1-30$.

Fortey, R.A. \& Barnes, C.R. 1977. Early Ordovician conodont and trilobite communities of Spitsbergen: influence on biogeography. Alcheringa, 1: 297-309.

McCracken, A.D. \& Barnes, C.R. 1981. Conodont biostratigraphy and paleoecology of the Ellis Bay Formation, Anticosti Island, Quebec, with special reference to Late Ordovician-Early Silurian chronostratigraphy and the systemic boundary. Geological Survey of Canada Bulletin, 329: 51-134.

Nowlan, G.S. \& Barnes, C.R. 1981. Late Ordovician conodonts from the Vaureal Formation, Anticosti Island, Quebec. Geological Survey of Canada Bulletin, 329: 1-49.

Nowlan, G.S. \& Barnes, C.R. 1987. Thermal maturation of Paleozoic strata in eastern Canada from conodont colour alteration index (CAI) data with implications for burial history, tectonic evolution, hotspot tracks and mineral and hydrocarbon potential. Geological Survey of Canada Bulletin, 367: 1-47.

Sweet, W.C., Ethington, R.L. \& Barnes, C.R. 1971. North American Middle and Upper Ordovician conodont faunas. In: Sweet, W.C. \& Bergström, S.M. (Eds), Symposium on Conodont Biostratigraphy. Geological Society of America Memoir, 127: 163-193.

Trotter, J.A., Williams, I.S., Barnes, C.R., Lécuyer, C. \& Nicoll, R.S. 2008. Did cooling oceans trigger Ordovician biodiversification: evidence from conodont thermometry? Science, 321: 550-554. 